\title{
Seasonal variability of turbidity, salinity, temperature and suspended chlorophyll in a strongly tidal sub-estuary: The Lynher Marine Conservation Zone
}

\author{
R. J. Uncles ${ }^{\mathrm{a}, *}$, T. Hooper ${ }^{\mathrm{b}}$, J.A. Stephens ${ }^{\mathrm{a}}$ and C. Harris ${ }^{\mathrm{a}}$ \\ ${ }^{a}$ Plymouth Marine Laboratory, Prospect Place, Plymouth PL1 3DH, UK \\ ${ }^{b}$ Seas Life Ltd., St. Germans, Cornwall, UK
}

\begin{abstract}
The Lynher Estuary in southwest England is a small, strongly tidal sub-estuary of the Tamar Estuary. It is a Site of Special Scientific Interest (SSSI), a Marine Conservation Zone (MCZ), a part of the Plymouth Sound and Estuaries Special Area of Conservation (SAC) and a Special Protection Area (SPA). Management of the Lynher SSSI and MCZ stipulates that good water quality and sediment quality should be maintained; as such, a good understanding of its responses to influences such as climate change and changes in agricultural practices within its catchment area is required. Observations of salinity, temperature, suspended particulate matter (SPM) concentrations, estuarine turbidity maximum (ETM) behaviour, and chlorophyll- $a$ are presented for the Lynher over a 1-y period. The dataset provides important baseline information with which to identify future changes and guide management of the SSSI and MCZ as well as adding to our knowledge of estuarine systems. Salt intrusion is largely controlled by tides and runoff. A persistent ETM occurs that is closely associated with the freshwater-saltwater interface at high water (HW) and with a minimum in dissolved oxygen concentrations. HW depth-averaged ETM magnitudes are relatively low, less than 60 $\mathrm{mg} \mathrm{l}^{-1}$ and typically $30 \mathrm{mg} \mathrm{l}^{-1}$ over the observation period. Larger tides and stronger floodtide wind speeds lead to a stronger ETM. Tidal river HW SPM concentrations are intrinsically small ( $8 \pm 8 \mathrm{mg}^{-1}$ during the observation period). Surface chlorophyll- $a$ concentrations are low during winter (when they often peak near the ETM) and are much higher during spring and summer.
\end{abstract}

Keywords: Estuarine Turbidity Maximum; Salinity intrusion; Suspended Particulate Matter; Dissolved Oxygen; Chlorophyll- $a$; Lynher Estuary, UK

*Corresponding author.

E-mail address: rju@pml.ac.uk (R.J. Uncles) 


\section{Introduction}

The Lynher Estuary in Southwest England (Fig. 1a, b, c) is a sub-estuary of the Plymouth Sound and Estuaries Special Area of Conservation (SAC) that covers an area of approximately $64 \mathrm{~km}^{2}$ (JNCC, 2017). This SAC is representative of ría estuaries in the southwest of England. The Lynher is confluent with, and a sub-estuary of, the Tamar Estuary (Fig. 1b, c) and is partially within the Tamar Estuary Marine Conservation Zone (MCZ) regions (JNCC, 2017). These MCZs are located in two spatially separate areas and cover an area of approximately $15 \mathrm{~km}^{2}$ that includes the upper reaches of the Tamar and Lynher Estuaries, which are the only areas in the southwest of England where there is good evidence for use by the mobile FOCI (Feature of Conservation Importance) Osmerus eperlanus (smelt).

The Lynher Estuary was notified as a Site of Special Scientific Interest (SSSI) in 1987 (Natural England, 2018a). The reasons for its notification highlighted the extensive saltmarsh and highly productive mudflats that provide important feeding and roosting grounds for large populations of wintering wildfowl and waders as well as its relatively unimpeded freshwater inputs from the rivers Tiddy and Lynher, which generate a gradient of salinity along which transitional marsh communities have developed (Natural England, 2018a). Management of the SSSI stipulates that 'good water quality and sediment quality should be maintained and that the sediment budget within the system should not be restricted by anthropogenic influences' (Natural England, 2018b). Some condition-status monitoring has taken place for the Lynher that has facilitated an assessment of the present favourable condition of its littoral sediment habitats and identified species and biotopes that are representative or notable within the estuary (Ecospan, 2015). Nevertheless, the extent and status of its saltmarshes, mudflats and littoral sediment habitats are ultimately dependent on the estuary's salinity gradients and its fine-sediment transport, which are sensitive to dynamic physical processes within the 
estuary and catchment that vary with agricultural use and with altered freshwater inputs and rising sea levels due to climate change. A baseline dataset on physical variables and an interpretation and quantitative understanding of its physical behaviour therefore provide important information with which to guide future management of the SSSI and MCZ.

Accordingly, we describe results from fieldwork in this small, strongly tidal estuary that over a year illustrate seasonal and spring-neap variations in the mouth-to-head longitudinal distributions of salinity and suspended particulate matter (SPM) concentrations and the estuarine turbidity maximum (ETM), which are important drivers of saltmarsh and mudflat spatial extent and composition, as well as temperature and concentrations of suspended chlorophyll- $a$. Chlorophyll- $a$ is an important variable to include here because the Lynher has a tendency towards eutrophication and is considered moderately vulnerable to nutrient enrichment (Parr and Wheeler, 1996). Excess nutrient inputs are thought to be mainly due to diffuse agricultural pollution and, to a lesser extent, from sewage infrastructure (Ecospan, 2015). In view of a potential oxygen demand in the estuary, some discussion is also given of dissolved oxygen concentrations (DO).

Although the ETM is usually studied as a physical phenomenon, it can have a profound influence on the ecology of an estuary (e.g. Garnier et al., 2010; Savoye et al., 2012; Keller et al., 2014), and whereas some work has been published on ETM behaviour in small estuaries (e.g. Jago et al., 2006; Uncles and Stephens, 2010), much of the research relates to larger estuaries (e.g. Purnachandra Rao et al., 2011; Sommerfield and Wong, 2011; Ralston et al., 2012; Jiang et al., 2013; Yu et al., 2014; Jalón-Rojas, 2016; Kitheka et al., 2016; Toublanc et al., 2016). Despite the SSSI designation of the Lynher, very little information on its physical regime has been published and previous studies have focussed on its biology (Joint., 1978; Warwick and Price, 1979; Bayne et al., 1987) or its contaminants (Bland et al., 1982; Austen and McEvoy, 1997). A review of some biological, chemical and ecological studies of the 
Plymouth Sound and Estuaries SAC and SPA (including the Lynher Estuary) is given by Langston et al. (2003).

This article is intended to contribute both to our understanding of the Lynher Estuary as a guide to its future management and to add to our knowledge of salt intrusion, ETM processes, seasonal variability and its consequences for chlorophyll- $a$ in small estuaries using measurements from this little-studied SSSI. The issues addressed here that are significant to the Lynher as a Marine Protected Area include: (1), salinity intrusion and its dependence on environmental forcing factors (determining the salinity gradients along which transitional marsh communities have developed); (2), suspended sediment concentrations and sediment transport in the tidal river and estuary, including the ETM (contributing to and interacting with the extensive saltmarsh and highly productive mudflats and subject to the requirement that the sediment budget within the system should not be restricted by anthropogenic influences); (3), chlorophyll- $a$ concentrations and the measurement of dissolved oxygen levels (in the knowledge that good water quality and sediment quality should be maintained). Particularly important aims include: examination of the sensitivity of salinity intrusion and ETM location and magnitude to tidal range and freshwater inflow from the catchment; the presence or otherwise of unusually elevated chlorophyll- $a$ levels as an indicator of excessive or normal nutrient levels; and the existence or absence of dissolved oxygen 'sags' as an indicator of potential water quality issues.

\section{The Lynher Estuary}

The Lynher Estuary is approximately $13 \mathrm{~km}$ long from its mouth in the lower Tamar Estuary $(x=12.5 \mathrm{~km}$, Fig. 1b, c) to its tidal limit at the weir $(\mathrm{x}=-0.5 \mathrm{~km}$, Fig. 1c), where $\mathrm{x}$ is the centre-line (i.e. midway between adjacent estuary banks/shores) distance along the estuary. The distance origin (at $\mathrm{x}=0 \mathrm{~km}$ ) is chosen to be Notter Bridge (Fig. 1c) because the great majority of surveys started at this station and only two started farther up-estuary $(\mathrm{x}=-$ 
0.23 and $-0.25 \mathrm{~km}$ ) during the HW stands of very large spring-tide, low-runoff surveys. The Lynher is a shallow estuary, typically less than 5-m deep at high water (HW). In the lower estuary it has extensive intertidal mudbanks and saltmarsh areas, whereas the upper estuary is river-like in appearance. Surveys undertaken in 2010 noted that the designated intertidal features of interest were in a favourable condition but that there were indications of vulnerability to nutrient enrichment (Ecospan, 2015).The most recent site-condition monitoring, undertaken in 2014, compared the extent of habitat with aerial photography from 1988 to 2009 (Natural England, 2014). The great majority of the intertidal areas are considered to be in favourable status (Seebold, 2016; Natural England, 2014; Ecospan, 2015); principal threats are identified as contaminants in water and sediment, elevated residual nutrient levels and a low infaunal quality index.

The estuary receives freshwater inflows from the River Lynher at the weir and from its sub-estuary of the Tiddy $\left(\mathrm{x}=5 \mathrm{~km}\right.$, Fig. 1c). Its catchment area is $173 \mathrm{~km}^{2}(\mathrm{IH}, 2003)$ and its daily-averaged freshwater input from both the Lynher and Tiddy Rivers during 1976 to 2016 ranged from less than 0.5 to greater than $70 \mathrm{~m}^{3} \mathrm{~s}^{-1}$, with a long-term mean of $5.5 \mathrm{~m}^{3} \mathrm{~s}^{-1}$; the Tiddy flow typically was $20 \%$ of the Lynher River flow and its mean flow was $1 \mathrm{~m}^{3} \mathrm{~s}^{-1}$ (daily-averaged data supplied by the UK's Environment Agency, UKEA). During the survey period, August 2002 to July 2003, daily-averaged freshwater input from both the Lynher and Tiddy Rivers ranged from less than 1.0 to greater than $50 \mathrm{~m}^{3} \mathrm{~s}^{-1}$, with a long-term mean of $5.0 \mathrm{~m}^{3} \mathrm{~s}^{-1}$; the Tiddy flow typically was only $26 \%$ of the Lynher River flow and its mean flow was $1 \mathrm{~m}^{3} \mathrm{~s}^{-1}$.

Some features of the tidal regime of the Lynher have been documented by George (1975). Tides are semi-diurnal with mean neap and spring ranges, respectively, of 2.2 and $4.7 \mathrm{~m}$ (Admiralty Tide Tables, 2017). 


\section{Methods}

A sea-truck was anchored close to the confluence of the Lynher and Tiddy (Fig. 1c) and a small inflatable boat used to survey 12 stations close to $\mathrm{HW}$ along the main channel of the Lynher between Notter Bridge (at $0 \mathrm{~km}$ and located $0.5 \mathrm{~km}$ down-estuary of the weir) and the Lynher-Tiddy confluence, which included the tidal river and ETM region. The sea-truck was then used to sample three remaining stations between the confluence and the Lynher mouth. A YSI multiparameter probe (YSI, 2017) was used to obtain vertical profiles of conductivity, temperature, salinity, turbidity and dissolved oxygen from $0.1 \mathrm{~m}$ above the bed to the surface. Data were logged using a 5-s sampling cycle; i.e., all variables, including date, time and depth, were measured and recorded every $5 \mathrm{~s}$. Synoptic calibration samples (one or more 500 $\mathrm{ml}$ bottles per station) were collected at the surface. Additional surface samples were collected using $2500 \mathrm{ml}$ dark glass Winchester bottles at each station for chlorophyll- $a$ analysis and surface-salinity determination using standard methods (e.g. Uncles and Mitchell, 2017). There were 20 surveys between 13 August 2002 and 21 August 2003, comprising 9 spring tides and 11 neap tides, with a spring and neap tide each month except for December 2002 (neap only) and January and July 2003 (springs only) and February, June and August 2003 (neaps only).

The surface water samples were analyzed in the laboratory. Salinity was measured with a laboratory-based bench salinometer (Guildline Portasal; www.guildline.com). SPM was determined gravimetrically by filtering known volumes of sampled water onto a pre-weighed $\mathrm{GF} / \mathrm{F}$ filter paper. Filters were then dried in a desiccator and weighed. Chlorophyll- $a$ was measured in samples filtered onboard the sea-truck following collection onto $47 \mathrm{~mm}$ Whatman GF/F filters. Pigments were extracted with $90 \%$ acetone and analyzed according to the fluorometric method of Yentsch and Menzel (1963). 
Wind data (University of Plymouth meteorological data; www.plymouth.ac.uk), Freshwater inflow data (UKEA, nrfa.ceh.ac.uk) and tidal data (Admiralty tide tables, www.admiralty.co.uk) were collated for the survey period of August 2002 to August 2003.

\section{Results}

The observations presented here were depth averaged to provide a synthesis of the important temporal and along-estuary features, excluding the longitudinal location of the salinity-1 contour, which was derived from the position at which that contour intersected the estuary bed, and the chlorophyll- $a$ data and their associated salinity values, which were measured using surface samples.

\subsection{Major seasonal variations: The Lynher mouth and tidal river}

The most up-estuary station in the tidal river (salinity $<0.1$, usually located at Notter Bridge, $x=0$, but farther up-estuary at $x=-0.23$ and $-0.25 \mathrm{~km}$ on two occasions, Fig. 1c) and the Lynher mouth station close to the confluence with the Tamar Estuary (at $\mathrm{x}=11.9 \mathrm{~km}$, Fig. 1c) showed a strong seasonal cycle for HW temperature that ranged from $6.6^{\circ} \mathrm{C}$ in January to $18.6^{\circ} \mathrm{C}$ in August (Fig. 2a). The HW salinity in the tidal river was always $<0.1$, whereas at the mouth of the Lynher it ranged between 34.3 in October and 25.5 in January (Fig. 2b). HW SPM concentrations in the tidal river and at the mouth were relatively low ( $8 \pm 8$ and $9 \pm 7 \mathrm{mg}^{-1}$, respectively) and did not exhibit seasonal variability (Fig. 2c); the large SPM peak on 10 September 2002 followed a prolonged period of large tides and, therefore, pronounced sediment resuspension in the Tamar Estuary (Uncles and Stephens, 1989). Chlorophyll- $a$ concentrations generally were less than $2 \mu \mathrm{g}^{-1}$ (Fig. 2d) but during May through September had values up to $25 \mu \mathrm{g}^{-1}$ in the mouth after a several-day period of small tides and up to $9 \mu \mathrm{g} \mathrm{l}^{-1}$ in the tidal river during a small, May 2003 runoff 'event'.

\subsection{A spring-tide longitudinal survey}


As an illustration of vertical and longitudinal structure, a HW survey of the Lynher Estuary during a low runoff, large spring tide (10 September, 2002) showed saltwater intrusion into the upper reaches (Fig. 3b) that exhibited strong vertical and longitudinal salinity gradients close to the freshwater-saltwater interface (FSI). At low water (LW; marked on Fig. 3a-c) the estuary would have comprised a narrow channel of fresh and brackish waters that extended to the deeper waters a few kilometres up-estuary of the LynherTamar confluence (the mean LW rather than the mean-spring LW drying line is shown in Fig. 1c). These LW Lynher waters were pushed back into the upper Lynher by flooding Tamar waters to form the HW tidal river and FSI region.

The temperature (heat content) of the flooding Tamar waters was essentially conservative on the flood-tide timescale (i.e. approximately linear when plotted versus salinity) and exhibited a similar structure to the salinity distribution (Fig. 3a, b). Similarly, HW SPM concentrations (Fig. 3c) were approximately conservative for salinity values between 2 and 33, indicating strong mixing between intruding Tamar waters and LW Lynher waters, with considerable scatter and SPM additions due (presumably) to sediment or detritus resuspension. HW SPM concentrations rose from approximately 45 to $60 \mathrm{mg}^{-1}$ in the newly mixed flood-tide waters but were less near the mouth and in the tidal river (but exceeded 30 $\mathrm{mg}^{-1}$ ). An estuarine turbidity maximum (ETM) therefore occurred near the limit of saline intrusion within the upper Lynher close to HW. The ETM region coincided with a dissolved oxygen DO minimum (not shown).

Although the ETM was a pronounced feature of this large spring tide, all 20 surveys exhibited an ETM that varied in magnitude and location throughout the year, together with a dissolved-oxygen minimum (DO 'sag') that was located in the upper estuary within the ETM region and close to the limit of saline intrusion.

\subsection{Locations of the FSI, ETM and the DO minimum}


The location of the near-bed salinity-1 contour at HW, $X_{S_{1}}$, was used as a measure of salt intrusion and the position of the FSI. Trial and error multiple regression analyses of measured variables using environmental data on tidal ranges, winds and freshwater inflows (Table 1) determined the strongest empirical correlations between these variables. The 20 surveys showed that $X_{S_{1}}$ was most closely correlated with the River Lynher freshwater inflow as recorded at the start of each survey $\left(Q_{L, 0}\right.$, Table 1$)$ and was larger (farther down-estuary) at higher inflows. The FSI location (measured as $X_{S_{1}}$ ) was also farther down-estuary during smaller tides (smaller tidal ranges, $R_{0}$ ). $X_{S_{1}}$ varied between $2.6 \mathrm{~km}$ down-estuary of Notter Bridge to $0.16 \mathrm{~km}$ up-estuary, with a mean value of $1 \mathrm{~km}$ down-estuary of the bridge, at a section where the HW width was approximately $20 \mathrm{~m}$ (Fig. 1c).

The location of the ETM, $X_{E T M}$, correlated strongly with the location of the FSI and moved up or down estuary in qualitative unison with $X_{S_{1}}$ (Table 1). In addition, westerly winds during the flooding tide, $W_{W, \text { flood }}$, correlated with an up-estuary movement of $X_{E T M}$. A similar, but not statistically significant wind effect was indicated for $X_{S_{1}} \cdot X_{E T M}$ varied between $7 \mathrm{~km}$ and $0.3 \mathrm{~km}$ down-estuary of Notter Bridge, with a mean value of $3 \mathrm{~km}$ downestuary of the bridge (Fig. 1c). Therefore, on average, the ETM was located $2 \mathrm{~km}$ downestuary of the FSI at HW. Westerly winds during the flooding tide decreased the ETM-FSI separation, whereas increasing freshwater inflows increased it $\left(R^{2}\right.$ of 0.58 and a Prob $>F$ of $<0.001$ with $19 \mathrm{DoF}) . X_{E T M}$ was located in waters of salinity that varied between 5 and 20 .

The location of the DO minimum, $X_{D O \min }$, was positively correlated both with the FSI and the ETM locations (Table 1). It varied between $7 \mathrm{~km}$ and $0.8 \mathrm{~km}$ down-estuary of the bridge and was located, on average, $2.6 \mathrm{~km}$ down-estuary; i.e., $1.6 \mathrm{~km}$ down-estuary of the FSI and 
$0.4 \mathrm{~km}$ up-estuary of the maximum SPM concentration, on average, and within the ETM region. $X_{D O \text { min }}$ was located in waters of salinity that varied between 24 and 8 .

\subsection{Salinity and SPM concentrations}

The seasonal variability exhibited by HW salinity at the survey station close to the Lynher mouth (Fig. 2b), which is confluent with the much larger Tamar Estuary, was most strongly correlated with the average Tamar Estuary runoff over the preceding 14 days $\left(Q_{T, 14 d}\right)$ and, to a lesser extent, with the average tidal range during the preceding 6 days $\left(R_{6 d}\right)$; larger tides over this 6-d period led to higher salinity at the mouth (Table 1). Similarly, a correlation existed between wind speed averaged over the preceding 3 days and HW salinity, with stronger winds tending to reduce the Lynher-mouth salinity.

The seasonal and monthly variations in SPM concentration at the mouth station, $P_{\text {mouth }}$ (Fig. 2b) could not be accurately described using the chosen environmental factors of wind speed, runoff and tides. However, excluding three high-concentration SPM outliers for August of 2002 and 2003 led to good correlations (all positive, Table 1) between the ETM magnitude, $P_{E T M}$, and $P_{\text {mouth }}$, the tidal range $R_{0}$ and the wind speed during the flooding tide, $W_{\text {flood }} . P_{E T M}$ was larger than $P_{\text {mouth }}$ by between 4 and $70 \mathrm{mg}^{-1}$ and the mean difference was $23 \mathrm{mg} \mathrm{l}^{-1}$.

The seasonal and monthly variations in HW tidal river SPM concentration measured at the most up-estuary station, $P_{\text {tidal-river }}$, were correlated with the HW SPM concentration at the Lynher mouth station (positively), the tidal range (negatively) and wind speeds over the preceding 3 days (positively), $W_{3 d}$ (Table 1). SPM concentrations had a marked influence on DO concentrations and the recorded DO minima over the observation period were strongly, negatively correlated with the SPM concentration at position $X_{D O \min }$ (Table 1). 


\subsection{Seasonal variations in the longitudinal distributions}

An ETM was formed in the upper estuary of the Lynher during the observational period (shown up to July 2003 in Fig. 4). Except for the relatively high runoff January survey (Fig. 4f) the ETM was located up-estuary of the confluence of the Tiddy and the Lynher (Fig. 1c) and less than $5 \mathrm{~km}$ from Notter Bridge in the very narrow and shallow part of the upper estuary, typically at $3 \mathrm{~km}$, where widths are $<100 \mathrm{~m}$ and depths $<4 \mathrm{~m}$ at $\mathrm{HW}$ of large tides. The large August neap-tide ETM (Fig. 4a) followed a 1-day peak in runoff after a sustained period of low and decreasing inflows and might have been enhanced by the presence of newly imported sediment from the catchment. The rapid rise in SPM from tidal river to estuary was closely associated with the FSI (salinity shown in Fig. 4).

Surface chlorophyll- $a$ was less than about $3 \mu \mathrm{g}^{-1}$ throughout the estuary during November through March (Fig. 5d-h) and, compared with the tidal river, tended to show somewhat higher values in the estuary. April concentrations increased to $4 \mu \mathrm{gl}^{-1}$ (Fig. 5i) and then to $10 \mu \mathrm{g}^{-1}$ during the large spring tide of May (Fig. 5j), with highest values in the tidal river. Bloom conditions (up to $25 \mu \mathrm{g}^{-1}$ ) occurred down-estuary of the ETM during the June neap tide (Fig. 5k) and during the July spring tide (Fig. 5l). The highest concentrations occurred during the September neap tide (Fig. 5a) when concentrations increased dramatically down-estuary of the tidal river and reached $75 \mu \mathrm{g} 1^{-1}$ at a location where the surface salinity was 27 .

\section{Discussion}

The Plymouth Sound and Estuaries system (Fig. 1b) was designated as a Special Area of Conservation (SAC) in 2005 under the European Habitats Directive (92/43/EEC) for features including its estuaries, large shallow inlets and bays, mudflats and salinity-graded biological communities (JNCC, 2017). The conservation objective for the SAC is to maintain the estuaries in favourable condition and the advice for relevant authorities is to manage human 
activities so that they do not result in deterioration or disturbance including increased siltation of the estuary bed or intertidal communities, abrasion of the estuarine habitats or nutrient/organic enrichment and/or increases in turbidity. However, such conservation objectives and advice for this and other SACs are qualitative aspirations without the type of quantitative background data on sediments, salinity and water quality and their interpretations that have been presented here for the Lynher Estuary.

The Lynher is a sub-estuary of the much larger Tamar and forms part of the Plymouth Sound and Estuaries SAC (Fig. 1b). It receives its high-salinity waters from the Tamar during the flooding tide and flushes most of these waters back into the Tamar during the ebbing of larger tides. This interdependence of waters, solutes and suspended sediments means that conservation objectives must be adhered to throughout the system and that processes, including physical processes, in all the sub-systems must be understood if the SAC as a whole is to be understood. The fresh and brackish waters that remain in the Lynher over LW are pushed back into the upper Lynher during the flood and are partially mixed with the incoming waters to produce vertical and longitudinal gradients in SPM, temperature, salinity and other solutes; lower salinity, relatively buoyant waters will be mixed into the upper water column and a relatively sharp longitudinal FSI will be generated separating predominantly Tamar waters from tidal river and LW Lynher waters. These processes lead to the salinity gradients that have been highlighted as of particular importance to the transitional marsh communities that have developed along them, which vary from saltmarsh to freshwater fen and willow carr (Natural England, 2018a). Saltmarsh vegetation communities range from pioneer stands of Townsend's Cord-grass and Sea Aster through lower-mid marsh with Common Saltmarsh-grass Puccinellia maritima and Sea purslane, to mid-upper marsh and transition freshwater inundation communities. The saltmarshes and their adjacent mudflats provide important roosting and feeding grounds for large numbers of wintering wildfowl and 
waders (Natural England, 2018a). Therefore, an understanding of the salinity distribution and its dependence on environmental forcing is a prerequisite for predicting how these communities may change with such forcing.

The work presented here has shown that the extent of salinity intrusion in the Lynher Estuary is largely controlled by tides and freshwater runoff from the River Lynher, the latter being very dependent on climate and anthropogenic changes within the catchment, and is such that larger tides increase intrusion and decrease vertical salinity gradients and larger runoff reduces intrusion and increases vertical gradients, which is similar to salinity behaviour in the Tavy sub-estuary (Fig. 1b, Uncles and Stephens, 2011) and many other estuaries (e.g., Xu et al. 2008; Becker et al., 2010; Ralston et al., 2010; Giddings et al., 2011). The salinity of incoming Tamar waters depends on the volume of freshwater runoff into the Tamar over the previous weeks, due to the delay caused by the Tamar's residence time for fresh water, which is roughly two weeks (Uncles and Stephens, 1990), and again emphasizes the interdependence of the sub-systems of the Plymouth Sound and Estuaries SAC. A period of larger tides over the previous several days similarly leads to incoming waters that have higher salinity, whereas a period of stronger winds tends to reduce the Lynher-mouth salinity at HW, which may be caused by wind-enhanced vertical mixing and reduced gravitational circulation (e.g. Officer, 1976) in the lower Tamar Estuary, thereby increasing the residence time of fresh water there. The influence of wind effects on salinity distributions and salinity stratification has been observed in numerous other estuaries (e.g., Barlow, 1956; Goodrich et al., 1987; Van de Kreeke and Robaczewska, 1989; Blumberg and Goodrich, 1990; Geyer, 1997; Dellapenna et al., 1998; Scully et al., 2005; Xu et al. 2008; Chen and Sanford, 2009; Behrens et al., 2016).

The Lynher has a small but persistent ETM that is closely associated with the FSI and located typically $2 \mathrm{~km}$ farther down-estuary at HW. The existence of the ETM and its 
changing SPM concentration and position with changing environmental forcing, as delineated here, demonstrates that fine-sediment transport is not simply conservative, i.e. linearly related to salinity, but has a dynamic component associated with water-column particle settling, deposition and resuspension, and that it therefore influences the morphology and composition of the intertidal mudflats, which have been highlighted as highly productive and providing important feeding and roosting grounds for large populations of birds. Depthaveraged ETM magnitudes were less than $60 \mathrm{mg} \mathrm{l}^{-1}$ and typically $30 \mathrm{mg}^{1^{-1}}$ over the observation period, although the SPM concentrations of incoming Tamar waters at HW typically were $10 \mathrm{mg} \mathrm{l}^{-1}$ but would have been greater at the start of the flood because of longitudinal gradients of SPM within the Tamar, where concentrations increase progressing up-Tamar. A regression equation for ETM magnitude based on mean spring tidal range and tidal length, and derived from numerous estuaries worldwide (Uncles et al., 2002a), estimates the Lynher ETM to be $\sim 30 \mathrm{mg} \mathrm{l}^{-1}$. An ETM of similar magnitude also occurs in the Tavy subestuary (Fig. 1b), close to the limit of salt intrusion at HW, where concentrations typically are less than $40 \mathrm{mg} \mathrm{l}^{-1}$ at $\mathrm{HW}$, although they can exceed $80 \mathrm{mg}^{-1}$ when tides and winds are strong (Uncles and Stephens, 2010).

In the Lynher, the rapid increase in SPM from tidal river to estuary indicates three possible causes: scenario (a), weakly deposited fine sediment and detritus is eroded from the mudflats by the incoming, leading edge of the flooding tide and transported into the estuary; scenario (b), the Lynher waters remaining within the lower estuary at LW are themselves turbid and mix strongly with the incoming, less turbid Tamar waters; and scenario (c), the incoming Tamar waters possess their own longitudinal SPM and salinity gradients (Uncles and Stephens, 1990) that at the Lynher mouth have greatest SPM concentration and lowest salinity close to LW and which are then transferred into the Lynher on the flood. 
In the first case, scenario (a), if vertical gradients and mixing are ignored then the incoming tide will push the initially ebbing Lynher waters back up-estuary, forming a convergent front between them that moves into the upper estuary until it reaches its HW position. A greater area of mudflat becomes available for erosion as the water level rises and the faster flowing tidal waters immediately behind the leading edge of the flooding tide will, if they are fast enough, suspend the easiest-erodible sediment and detritus, thereby maximising the SPM concentration in this up-estuary-moving region. Because this process begins at the mouth of the Lynher at the start of the flood, the brackish and fresh river waters that eventually form the FSI lay in front (up-estuary) of the leading edge. The addition of mixing and vertical structure generates both an FSI and the potential for density-driven flow superimposed on the flood-tide currents, which would further accumulate SPM behind the FSI (e.g., Festa and Hansen, 1978). This scenario emphasizes the strong interactions between water-column processes and the mudflats that are an important feature of the Plymouth Sound and Estuaries SAC.

In scenario (b), if there is no flood-tide sediment erosion, mixing or vertical structure, then the turbid LW Lynher waters, with less turbid tidal river waters behind them, will be pushed back by the flooding, less-turbid Tamar waters and their SPM concentrations will remain the same. Including mixing and structure, then mixing will generate a non-frontal FSI between the Lynher and Tamar waters that will exhibit highest SPM concentrations at lower salinities, so that vertical structure and density-driven currents during the slack, late flood of the upper reaches will further accumulate SPM behind the FSI (e.g., Festa and Hansen, 1978). In this case, the longitudinal salinity gradient and freshwater inputs still play a key role in the distribution of SPM and salinity that affect saltmarsh development.

In scenario (c), the ETM concentrations are increased because of the longitudinal SPM gradient in the Tamar (Uncles and Stephens, 1989). Over the seasonal observation period the 
ETM magnitude was observed to be about $20 \mathrm{mg}^{-1}$ greater than the Lynher mouth SPM concentration at HW. An examination of historical Tamar data indicates that this longitudinal-gradient effect may be too small to account for the observed difference, although it could provide a significant contribution. In this case too, physical transport of salinity and SPM, this time from the Tamar, would affect the mudflats and marshes of the Lynher. The processes outlined in scenarios (a-c) have been observed in many other estuaries to varying degrees (e.g., Kessarkar et al., 2010; Uncles et al., 2010; Rao et al., 2011; Sommerfield and Wong, 2011; Ralston et al., 2012; Wu et al., 2012; Keller et al., 2014; Yu et al., 2014; Kitheka et al., 2016).

The HW SPM concentration at the Lynher mouth is greater after a period of large tides but less after a period of stronger winds (although the wind correlation was only marginally significant). The Tamar has a strong ETM in its upper reaches during spring tides (Uncles and Stephens, 1989), so that a delayed increase in SPM loads and a lagged dependence on tidal range can be anticipated for the lower Tamar. Increasing winds may also increase vertical mixing, reduce the gravitational circulation (e.g. Officer, 1976) and decrease the amount of fine SPM reaching the lower Tamar in its somewhat fresher, near-surface waters.

An increased HW SPM concentration at the Lynher mouth leads to a stronger HW ETM, as would be anticipated from flood-tide scenarios (a) and (c). Larger tides and stronger floodtide wind speeds also lead to a stronger ETM, indicating a potential increase in tidal and wind-induced suspension of sediment and detritus from the mudflats (scenario (a)) and increased mixing with LW Lynher waters (scenario (b)). The HW location of the ETM moves up or down estuary in qualitative unison with the FSI. Westerly winds during the flooding tide tend to produce an up-estuary movement of the ETM, which may be caused by a wind-reduced up-estuary tidal flow at the surface in the lower Lynher compensated-for by an enhanced up-estuary flow at the bed. 
Although intrinsically small $\left(8 \pm 8 \mathrm{mg} \mathrm{l}^{-1}\right)$, the tidal river HW SPM concentrations increase with greater Lynher mouth concentrations, which indicates a possible up-estuary, short-term response to the variable input of SPM from the Tamar to the Lynher. Possible HW deposition of SPM from turbid LW Lynher waters (scenario (b)) in the upper reaches would be eroded during the following, relatively fast-flowing freshwater river currents, allowing sediment to be mixed into tidal river waters prior to the following flood. The tidal river concentrations also increase following a period of stronger winds, potentially reflecting enhanced suspension of sediment and detritus into the tidal river during the LW period (scenario (b)). Smaller tides are associated with greater SPM concentrations in the tidal river, although the effect is small $\left(<5 \mathrm{mg} \mathrm{l}^{-1}\right.$ for the observed range of tides). Possible explanations are that smaller tides and less vertical mixing may enhance the near-bed density-driven flow and transport its sediment load into the upper reaches, or that previous higher tides deposit sediment onto the channelflanking bed of the upper reaches over their HW stands, which may then be eroded by small waves at the water edges during the lower HW stands of smaller tides.

Dissolved oxygen levels within estuaries are influenced by a range of physical, chemical and biological factors, including circulation (Scully, 2010), stratification, photosynthesis and water column and benthic oxygen demands, possibly associated with e.g. SPM, sediments or pollution events (e.g. Brown and Power, 2011; Chen et al., 2014; Testa and Kemp, 2014). Freshwaters carrying diffuse agricultural pollution and sewage, although to a lesser degree, are thought to affect the Lynher Estuary to some extent (Ecospan, 2015) and might produce a decrease in dissolved oxygen when encountering higher-turbidity saline waters. In the Lynher Estuary, the findings presented here show that the ETM exerts a control over the local DO, such that the minimum DO occurs within the ETM region and is strongly, negatively correlated with the SPM concentration at that location, indicating a potential water-quality issue. Morris et al. (1982) showed that the oxygen demand exerted within the ETM zone of 
the Tamar Estuary can generate a sharp drop in DO concentration down-estuary of the FSI. They attributed this primarily to the degradation of organic detritus within the ETM, but acknowledged that an oxygen demand by inflowing fluvial organic particles may play a role. In the extremely turbid Humber-Ouse Estuary, Uncles et al. (1998b) showed that there was a linear correlation between total bacterial number and SPM concentration, suggesting that the strong DO demand was exerted locally via bacterial activity associated with the SPM.

Management of the Lynher SSSI and MCZ stipulates that good water quality and sediment quality should be maintained and the sediment budget within the system should not be restricted by anthropogenic influences (Natural England, 2018c). However, because the Lynher has a tendency towards eutrophication and is considered moderately vulnerable to nutrient enrichment (Parr and Wheeler, 1996) it has been important to quantify chlorophyll- $a$ concentrations in order to provide a baseline dataset and to identify seasonal variability within it. Surface HW chlorophyll- $a$ concentrations in the Lynher showed a similar seasonal pattern to that in many other estuaries (e.g. Cloern et al., 1985; Cloern, 1987; Jackson et al., 1987; Malone et al., 1988; Uncles et al., 1998a; Philippart et al., 2010), having low values (< $3 \mu \mathrm{g}^{-1}$ ) during winter and much higher, 'bloom' values during spring and summer (up to 25 $\left.\mu \mathrm{g}^{-1}\right)$. In the Lynher, chlorophyll- $a$ peaked during a September neap tide $\left(75 \mu \mathrm{g}^{-1}\right)$ after several weeks of low and decreasing freshwater runoff. The recorded DO was strongly supersaturated during this bloom. Although chlorophyll- $a$ concentrations were very high, Cloern (1987) showed that during the summer bloom in Suisun Bay, northern San Francisco Bay, the chlorophyll- $a$ concentrations were consistently greater than $60 \mu \mathrm{g} \mathrm{l^{-1 }}$ on the shoals but less than $30 \mu \mathrm{g} \mathrm{l}^{-1}$ in the adjacent channel. Cloern (1987) also reported values exceeding $40 \mu \mathrm{g}^{-1}$ in South San Francisco Bay during stratified conditions in April. Philippart et al. (2010) analysed chlorophyll- $a$ data for the western Wadden Sea during the period 19742007; although they could not find any long-term trends in the start and end times of 
phytoplankton spring blooms they did show that spring bloom concentrations often exceeded $70 \mu \mathrm{g} \mathrm{l}^{-1}$ and that in two of the years concentrations exceeded $100 \mu \mathrm{g} \mathrm{l^{-1 }}$.

In the Lynher Estuary, chlorophyll- $a$ concentrations are very low during the winter months but often show a peak in the vicinity of the ETM that is likely caused by one of the mechanisms that produce the ETM (scenario (b)). Some other estuaries also show a peak of chlorophyll- $a$ close to the FSI; e.g., the spring bloom in Chesapeake Bay (Malone et al., 1988), the fluvial-dominated northern San Francisco Bay (Cloern et al., 1985), the turbid Humber-Ouse (Uncles et al., 1998a) and the Tamar (Jackson, 1987).

Climate change influences on coastal and estuarine systems will become increasingly important in the future. Global sea level is expected to continue rising, with recent assessments from the Intergovernmental Panel on Climate Change (IPCC) ranging from approximately 0.25 to $1 \mathrm{~m}$ during the $21^{\text {st }}$ century (Edwards, 2017). According to DEFRA (2014), future changes in river-flow magnitudes and groundwater recharges are uncertain, but it is likely that flows will be more variable, with higher high flows and lower low flows, and that the frequency of high intensity events (e.g. flushing, erosion and accretion) will increase, thereby affecting estuarine morphology. River, coastal and estuarine temperatures are also very likely to increase. A key risk is nutrient enrichment and its consequences, which will be influenced by hydrological and biogeochemical changes as well as land-use changes (DEFRA, 2014).

Changes in estuarine morphology will affect estuarine biology, e.g. mudflat biota; in addition, it is often assumed that sea-level rise will increase estuarine salinity and salinity intrusion, which in turn will cause an up-estuary shift in salinity-dependent species distributions and community composition (Little et al., 2017). However, Little et al. (2017) demonstrated that whilst salinity is a dominant factor in benthic species distribution and community composition, other factors play a role, such as substratum type (also likely to be 
affected by climate-change-induced erosion or deposition), biotic competition and predatorprey relationships. Saltmarsh vegetation communities will alter in response to changing salinity intrusion and changes to mudflat composition and spatial extent will affect wildfowl and waders. To complicate the issue, whilst rising sea levels in combination with reduced low-flow summer runoff will increase salinity intrusion compared with present conditions (e.g. Prandle and Lane, 2015), it is not clear that the same will apply during increased highflow winter runoff. For example, EA (2010) concluded that changes in river flow will affect vertical mixing and salinity intrusion, and whilst increases in river flow would only have significant impacts on vertical mixing in the shallower estuaries, it could lead to significant decreases in saline intrusion in any estuary, which would be substantially enhanced in shallow waters.

Higher high winter freshwater flows due to climate change and associated increased river sediment loads due to greater soil erosion in the catchment and nutrient loads (e.g. Uncles et al., 2002b) will result in abrasion of the estuary's bed and increased estuarine turbidity, as well as the potential for eutrophication and other water quality issues such as dissolved oxygen 'sags' in a system that is already recognised to be moderately vulnerable to nutrient enrichment and is considered to have a tendency towards eutrophication (Parr and Wheeler, 1996).

Finally, the Plymouth Sound and Estuaries SAC is a complex site to monitor and manage; it is one of the few SACs in England that comprises multiple estuaries, each of which has many different features and sub-features. Natural England is reviewing its approach to condition assessment to 'make better use of all available evidence relating to feature condition [including both] direct and indirect information'. Sampling the marine environment is difficult, which makes gathering robust evidence for condition assessments costly and time-consuming (Rush and Solandt 2017). In a complex environment such as an estuary with 
multiple potential impacts it is unrealistic to expect to establish strict causality between anthropogenic inputs and adverse impacts, and therefore advice should also be modelled on a 'revised approach' that will allow better integration of qualitative evidence and quantitative evidence (such as that presented here) for estuarine management (Marine Management Organisation, 2014). The significance of our quantitative evidence for the Lynher Estuary includes: the strong dependence of saline intrusion on catchment freshwater flow, which affects transitional marsh communities; the dependence of the ETM location (maximum SPM concentrations) to the saline intrusion and therefore catchment freshwater inflow, which affects saltmarshes, mudflats and the sediment budget; and the observation of normal suspended chlorophyll- $a$ levels but a routinely observed dissolved oxygen 'sag' near the ETM, which are relevant to water quality and sediment quality objectives.

\section{Conclusions}

Because management of the Lynher SSSI and MCZ stipulates that good water quality and sediment quality should be maintained and that the sediment budget within the system should not be restricted by anthropogenic influences, confidence in the intertidal mud features remaining in favourable status requires a good understanding of its responses to influences such as climate change and changes in agricultural practices within the catchment area. Potentially higher high winter freshwater runoff due to climate change and its increased sediment and nutrient loads will result in abrasion of the estuary's bed in its upper reaches, accretion nearer the mouth and increased estuarine turbidity, as well as possible eutrophication and dissolved oxygen 'sags' during subsequent summer months, so that chlorophyll- $a$ is an important variable to measure if good water quality is to be monitored and maintained. Lower low summer freshwater runoff and sea-level rise is likely to increase estuarine salinity and salinity intrusion and affect salinity-dependent species distributions and community composition. 
Our seasonal measurements show that salinity intrusion in the Lynher is largely controlled by tides and freshwater runoff. Larger tides increase intrusion and decrease vertical salinity gradients and larger runoff reduces intrusion and increases vertical gradients. The salinity of Tamar waters flooding into the Lynher depends on the volume of freshwater runoff into the Tamar over previous weeks. A period of larger tides over the previous several days leads to incoming waters of higher salinity, whereas a period of stronger winds tends to reduce the Lynher-mouth salinity at HW.

The Lynher has a persistent ETM that is closely associated with the FSI and located typically $2 \mathrm{~km}$ farther down-estuary at HW. The HW location of the ETM moves up or down estuary in qualitative unison with the FSI and the ETM magnitude appears to exert a control over the local DO, such that the minimum DO occurs within the ETM region and is strongly, negatively correlated with the SPM concentration at the minimum. The reasons for this are not known, but it is thought that freshwater inputs that might carry diffuse agricultural pollution and small amounts of sewage may play a role and could produce a decrease in dissolved oxygen when encountering saline waters and greater SPM loads.

Depth averaged ETM magnitudes are relatively low, less than $60 \mathrm{mg} \mathrm{l}^{-1}$ and typically 30 $\mathrm{mg} \mathrm{l}^{-1}$ over the observation period, although the SPM concentration of incoming Tamar waters at $\mathrm{HW}$ typically can account for at least $10 \mathrm{mg} \mathrm{l}^{-1}$ of this. Larger tides and stronger flood-tide wind speeds lead to a stronger ETM. An increased HW SPM concentration at the Lynher mouth leads to a stronger HW ETM and the HW SPM concentration at the Lynher mouth is itself greater after a period of large tides.

Although the tidal river HW SPM concentrations are small $\left(8 \pm 8 \mathrm{mg}^{-1}\right.$ during the observation period), they increase with greater Lynher mouth concentrations, indicating sediment deposition into the upper reaches during the HW stands of larger tides. The tidal river concentrations also increase following a period of stronger winds. 
Surface HW chlorophyll- $a$ concentrations in the Lynher show a similar seasonal pattern to that in many other estuaries, having low values during winter and much higher 'bloom' values during spring and summer when very high values can occur during neap tides after several weeks of low and decreasing freshwater runoff. Although chlorophyll- $a$ concentrations are very low during the winter months, they often show a peak in the vicinity of the ETM.

The results of this study provide an example of observations and analyses that can be shared to inform a more proactive and informed management of protected areas and that could be used to identify a threat before it leads to more significant damage to a feature within them.

\section{Acknowledgements}

RJU thanks Professor Steve de Mora, Chief Executive of the Plymouth Marine Laboratory, for the award of a Senior Research Fellowship. 


\section{References}

Admiralty Tide Tables, 2017. United Kingdom and Ireland (NP201B) Vol. 1B. The UK Hydrographic Office, Admiralty Way, Taunton, Somerset, UK.

Austen, M.C., McEvoy, A.J., 1997. Experimental effects of tributyltin (TBT) contaminated sediment on a range of meiobenthic communities. Environmental Pollution 96, 435-444.

Barlow, J.P., 1956. Effect of wind on salinity distribution in an estuary. Journal of Marine Research $15,193-203$.

Bayne, B.L., Hawkins, A.J.S., Navarro, E., 1987. Feeding and digestion by the mussel Mytilus edulis L. (Bivalvia: Mollusca) in mixtures of silt and algal cells at low concentrations. Journal of Experimental Marine Biology and Ecology 111, 1-22.

Becker, M.L., Luettich Jr., R.A., Mallin, M.A., 2010. Hydrodynamic behavior of the Cape Fear River and estuarine system: A synthesis and observational investigation of discharge-salinity intrusion relationships. Estuarine, Coastal and Shelf Science 88, 407-418.

Behrens, D. K., Bombardelli, F. A., Largier, J. L., 2016. Landward propagation of saline waters following closure of a bar-built estuary: Russian River (California, USA). Estuaries and Coasts 39, $621-638$

Bland, S., Ackroyd, D.R., Marsh, J.G., Millward, G.E., 1982. Heavy metal content of oysters from the Lynher Estuary, U.K. The Science of the Total Environment 22, 235-241.

Blumberg, A.F., Goodrich, D.M., 1990. Modeling of wind-induced destratification in Chesapeake Bay. Estuaries 13, 236-249.

Brown, CA., Power, J.H., 2011. Historic and recent patterns of dissolved oxygen in the Yaquina Estuary (Oregon, USA): Importance of anthropogenic activities and oceanic conditions. Estuarine, Coastal and Shelf Science 92, 446-455.

Chen, S.-N., Sanford, L.P., 2009. Axial Wind Effects on Stratification and Longitudinal Salt Transport in an Idealized, Partially Mixed Estuary. Journal of Physical Oceanography 39, 19051920. 
Chen, J., Ni, X., Liu, M., Chen, J., Mao, Z., Jin, H., Pan, D., 2014. Monitoring the occurrence of seasonal low-oxygen events off the Changjiang Estuary through integration of remote sensing, buoy observations, and modelling. Journal of Geophysical Research, Oceans 119, 5311-5322.

Cloern, J.E., Cole, B.E., Wong, R.L., Alpine, A.E., 1985. Temporal dynamics of estuarine phytoplankton: a case study of San Francisco Bay. Hydrobiologia 129, 153-176.

Cloern, J.E., 1987. Turbidity as a control on phytoplankton biomass and productivity in estuaries. Continental Shelf Research 7,1367-1381.

DEFRA, 2014. The consequences of climate change for the water environment in England: an assessment of the current evidence. Final report WT1540. Department for Environment, Food and Rural Affairs, Flood Risk Management Division, Nobel House, 17 Smith Square London SW1P 3JR. 69pp. www.defra.gov.uk

Dellapenna, T.M., Kuehl, S.A., Schaffner, L.C., 1998. Sea-bed Mixing and Particle Residence Times in Biologically and Physically Dominated Estuarine Systems: a Comparison of Lower Chesapeake Bay and the York River Subestuary. Estuarine, Coastal and Shelf Science 46, 777-795.

EA, 2010. Vulnerability of estuaries to sea level rise. UK Environment Agency Report: Project summary SC080016/S1, 2pp. www.gov.uk/go-science

Ecospan, 2015. Lynher Estuary SSSI Intertidal Biotope Survey 2010. Report: ER10:126. Ecospan Environmental Ltd., Unit 8 Embankment Lane, Plymouth, Devon PL4 9LQ. 56pp.

Edwards, T., 2017. Future of the Sea: Current and Future Impacts of Sea Level Rise on the UK. Future of the Sea Evidence Review: A Foresight Report, UK Government Office for Science. 39pp. Available from www.gov.uk/go-science

Festa, J.F., Hansen, D.V., 1978. Turbidity maxima in partially mixed estuaries: A two-dimensional numerical model. Estuarine and Coastal Marine Science 7, 347-359.

Garnier, J., Billen, G., Némery, J., Sebilo, M., 2010. Transformations of nutrients (N, P, Si) in the turbidity maximum zone of the Seine estuary and export to the sea. Estuarine, Coastal and Shelf Science 90, 129-141.

George, K.J., 1975. The tides and tidal streams of the Tamar Estuary, PhD Thesis, Univ. London, $555 \mathrm{pp}$. 
Geyer, W.R., 1997. Influence of wind on dynamics and flushing of shallow estuaries. Estuarine, Coastal and Shelf Science 44, 713-722.

Giddings, S. N., Fong, D. A., Monismith, S. G., 2011. Role of straining and advection in the intratidal evolution of stratification, vertical mixing, and longitudinal dispersion of a shallow, macrotidal, salt wedge estuary. Journal of Geophysical Research: Oceans 116, C03003.

Goodrich, D.M., Boicourt, W.C., Hamilton, P., Pritchard, D.W., 1987. Wind-Induced Destratification in Chesapeake Bay. Journal of Physical Oceanography 17, 2232-2240.

IH, 2003. Hydrological data United Kingdom. Institute of Hydrology, Wallingford, Oxon OX10 8BB, 208pp.

Jackson, R.H., Williams, P.J. le B., Joint, I.R., 1987. Freshwater phytoplankton in the low salinity region of the River Tamar Estuary. Estuarine, Coastal and Shelf Science 25, 299-311.

Jago, C.F., Ishak, A.K., Jones, S.E., Goff, M.R.G., 2006. An ephemeral turbidity maximum generated by resuspension of organic-rich material in a macrotidal estuary, S. W. Wales. Estuaries 29, 197 208.

Jalón-Rojas, I., Schmidt, S., Sottolichio, A., Bertier, C., 2016. Tracking the turbidity maximum zone in the Loire Estuary (France) based on a long-term, high-resolution and high-frequency monitoring network. Continental Shelf Research 117, 1-11.

Jiang, X., Lu, B., He, Y., 2013. Response of the turbidity maximum zone to fluctuations in sediment discharge from river to estuary in the Changiiang Estuary (China). Estuarine, Coastal and Shelf Science 131, 24-30.

JNCC, 2017. Joint Nature Conservation Committee. Monkstone House, City Road, Peterborough, PE1 1JY (Headquarters). Tel: +44 (0)1733 562626.

http://jncc.defra.gov.uk/protectedsites/sacselection/sac.asp?EUCode=UK0013111

Keller, D.P., Lee, D.Y., Hood, R.R., 2014. Turbidity maximum entrapment of phytoplankton in the Chesapeake Bay. Estuaries and Coasts 37, 279-298.

Kessarkar, P.M., Rao, V.P., Shynu, R., Mehra, P., Viegas, B.E., 2010. The Nature and Distribution of Particulate Matter in the Mandovi Estuary, Central West Coast of India. Estuaries and Coasts 33, $30-44$. 
Kitheka, J.U., Mavuti, K.M., Nthenge, P., Obiero, M., 2016. The turbidity maximum zone in a shallow, well-flushed Sabaki estuary in Kenya. Journal of Sea Research 110, 17-28.

Langston, W.J., Chesman, B.S., Burt, G.R., Hawkins, S.J., Readman, J., Worsfold, P., 2003.

Characterisation of the South West European Marine Sites. Plymouth Sound and Estuaries cSAC, SPA. Marine Biological Association of the United Kingdom Occasional Publications. 9, 202 pp.

Little, S., Wood, P.J., Elliott, M., 2017. Quantifying salinity-induced changes on estuarine benthic fauna: The potential implications of climate change. Estuarine, Coastal and Shelf Science 198, $610-625$.

Malone, T.C., Crocker, L.H., Pike, S.E., Wendler, B.W., 1988. Influence of river flow on the dynamics of phytoplankton production in a partially stratified estuary. Marine Ecology Progress Series 48, 235-249.

Marine Management Organisation, 2014. https://www.gov.uk/government/publications/revisedapproach-to-the-management-of-commercial-fisheries-in-european-marine-sites-overarchingpolicy-and-delivery

Morris, A.W., Loring, D.H., Bale, A.J., Howland, R.J.M., Mantoura, R.F.C., Woodward, E.M.S., 1982. Particle dynamics, particulate carbon and the oxygen minimum in an estuary. Oceanologica Acta 5, 349-353.

Natural England, 2014. Designated sites. Downloadable from: https://designatedsites.naturalengland.org.uk/ReportUnitCondition.aspx?SiteCode=S1004001\&Re portTitle=Lynher Estuary SSSI

Natural England, 2018a. Designated sites. Downloadable from: https://designatedsites.naturalengland.org.uk/PDFsForWeb/Citation/1004001.pdf

Natural England, 2018b. Public features. Downloadable from: https://designatedsites.naturalengland.org.uk/PDFsForWeb/VAM/1004001.pdf

Natural England, 2018c. Views about management. Downloadable from: https://designatedsites.naturalengland.org.uk/MarineCondition/PublicFeatures.aspx?SiteCode=UK $\underline{0013111}$ 
Officer, C.B., 1976. Physical oceanography of estuaries (and associated coastal waters). John Wiley and Sons, Inc., New York, 465 pp.

Parr, W., Wheeler, M., 1996. Trends in nutrient enrichment of sensitive marine areas in England. Report to English Nature from the Water Resources Council (WRc Report No. C04055/1).

Philippart, C.J.M., van Iperen, J.M., Cadée, G.C., Zuur, A.F., 2010. Long-term field observations on seasonality in chlorophyll- $a$ concentrations in a shallow coastal marine ecosystem, the Wadden Sea. Estuaries and Coasts 33, 286-294.

Prandle, D., Lane, A., 2015. Sensitivity of estuaries to sea level rise: vulnerability indices. Estuarine, Coastal and Shelf Science 160, 60-68.

Purnachandra Rao, V., Shynu, R., Kessarkar, P.M., Sundar, D., Michael, G.S., Narvekar, T., Blossom, V., Mehra, P., 2011. Suspended sediment dynamics on a seasonal scale in the Mandovi and Zuari estuaries, central west coast of India. Estuarine, Coastal and Shelf Science 91, 78-86.

Ralston, D.K., Geyer, W.R., Lerczak, J.A., 2010. Structure, variability, and salt flux in a strongly forced salt wedge estuary. Journal of Geophysical Research 115, C06005. doi:10.1029/2009JC005806.

Ralston, D.K., Geyer, W.R., Warner, J.C., 2012. Bathymetric controls on sediment transport in the Hudson River estuary: Lateral asymmetry and frontal trapping. Journal of Geophysical Research 117, C10013, doi:10.1029/2012JC008124.

Rao, V.P., Shynu, R., Kessarkar, P.M., Sundar, D., Michael, G.S., Narvekar, T., Viegas, B., Mehra, P., 2011. Suspended sediment dynamics on a seasonal scale in the Mandovi and Zuari estuaries, central west coast of India. Estuarine, Coastal and Shelf Science 91, 78-86.

Rush, S., Solandt, J.L., 2017. Challenges on providing conservation advice for a growing network of English Marine Protected Areas. Marine Policy 83, 75-82.

Savoye, N., David, V., Morisseau, F., Etcheber, H., Abril, G., Billy, I., Charlier, K., Oggian, G., Derriennic, H., Sautour, B., 2012. Origin and composition of particulate organic matter in a macrotidal turbid estuary: The Gironde Estuary, France. Estuarine, Coastal and Shelf Science 108, $16-28$. 
Scully, M.E., Friedrichs, C., Brubaker, J., 2005. Control of estuarine stratification and mixing by wind-induced straining of the estuarine density field. Estuaries 28, 321-326.

Scully, M.E., 2010. Wind modulation of dissolved oxygen in Chesapeake Bay. Estuaries and Coasts $33,1164-1175$.

Seebold, R., 2016. Plymouth Sound and Estuaries SAC/SSSI: 2013 saltmarsh condition assessment survey report. Natural England Evidence Project Report RP01513.

Sommerfield, C.K., Wong, K.-C., 2011. Mechanisms of sediment flux and turbidity maintenance in the Delaware Estuary. Journal of Geophysical Research 116, C01005, doi:10.1029/2010JC006462

Testa, J.M., Kemp, W.M., 2014. Spatial and temporal patterns of winter-spring oxygen depletion in Chesapeake Bay bottom water. Estuaries and Coasts 37, 1432-1448.

Toublanc, F., Brenon, I., Coulombier, T., 2016. Formation and structure of the turbidity maximum in the macrotidal Charente estuary (France): Influence of fluvial and tidal forcing. Estuarine, Coastal and Shelf Science 169, 1-14.

Uncles, R.J., Stephens, J.A., 1989. Distributions of suspended sediment at high water in a macrotidal estuary. Journal of Geophysical Research 94, C10, 14,395-14,405.

Uncles, R.J., Stephens, J.A., 1990. Computed and observed currents, elevations, and salinity in a branching estuary. Estuaries 13, 133-144.

Uncles, R.J., Easton, A.E., Griffiths, M.L., Harris, C., Howland, R.J.M., Joint, I., King, R.S., Morris, A.W., Plummer, D.H., 1998a. Concentrations of suspended chlorophyll in the tidal Yorkshire Ouse and Humber Estuary. The Science of the Total Environment 210/211, 367-375.

Uncles, R.J., Joint, I.R., Stephens, J.A., 1998b. Transport and retention of suspended particulate matter and bacteria in the Humber-Ouse estuary, United Kingdom, and their relationship to hypoxia and anoxia. Estuaries 21, 597-612.

Uncles, R.J., Stephens, J.A., Smith, R.E., 2002a. The dependence of estuarine turbidity on tidal intrusion length, tidal range and residence time. Continental Shelf Research 22, 1835-1856.

Uncles, R.J., Fraser, A.I., Butterfield, D., Johnes, P., Harrod, T.R., 2002b. The prediction of nutrients into estuaries and their subsequent behaviour: application to the Tamar and comparison with the Tweed, UK, Hydrobiologia, 475/476, 239-250. 
Uncles, R.J., Stephens, J.A., 2010. Turbidity and sediment transport in a muddy sub-estuary.

Estuarine, Coastal and Shelf Science 87, 213-224.

Uncles, R.J., Bale, A.J., Stephens, J.A., Frickers, P.E., Harris, C., 2010. Observations of Floc Sizes in a Muddy Estuary. Estuarine, Coastal and Shelf Science 87, 186-196.

Uncles, R.J., Stephens, J.A., 2011.The effects of wind, runoff and tides on salinity in a strongly tidal sub-estuary. Estuaries and Coasts 34, 758-774.

Uncles, R.J., Mitchell, S.B., 2017. Estuarine and coastal hydrography and sediment transport. CUP, Cambridge, 351pp.

Van de Kreeke, J., Robaczewska, K., 1989. Effect of wind on the vertical circulation and stratification in the Volkerak Estuary. Netherlands Journal of Sea Research 23, 239-253.

Warwick, R.M., Price, R., 1979. Ecological and metabolic studies on free-living nematodes from an estuarine mud-flat. Estuarine and Coastal Marine Science 9, 257-271.

Wu, J., Liu, J.T., Wang, X., 2012. Sediment trapping of turbidity maxima in the Changjiang Estuary. Marine Geology 303-306, 14-25.

Xu, H., Lin, J., Wang, D., 2008. Numerical study on salinity stratification in the Pamlico River Estuary. Estuarine, Coastal and Shelf Science 80, 74-84.

Yentsch, C.S., Menzel, D.W., 1963. A method for the determination of phytoplankton chlorophyll and phaeophytin by fluorescence. Deep Sea Research 10, 221-231.

YSI, 2017. YSI Incorporated, 1700/1725 Brannum Lane, Yellow Springs, OH 45387, USA. https://www.ysi.com/products/multiparameter-sondes

Yu, Q., Wang, Y., Gao, J., Gao, S., Flemming, B., 2014. Turbidity maximum formation in a wellmixed macrotidal estuary: The role of tidal pumping. Journal of Geophysical Research 119, 77057724, doi:10.1002/2014JC010228. 


\section{Figure and Table Captions}

\section{Table}

Table 1. Multiple regression results for measured and derived variables from 20 surveys of the Lynher Estuary between August 2002 and August 2003. The degrees of freedom (DoF) generally comprise 19 data (20 minus the intercept determination) of which one to three accommodate the regression model (one to three slopes of the regression for one to three 'parameters' - respectively) and 16 to 18 accommodate minimisation of the regression error. $R^{2}$ is the Coefficient of Determination (the proportion of variance 'explained').

\section{Figures}

Figure 1. Maps showing: (a), the location of the Lynher Estuary in southwest England, UK; (b), the location of the Lynher Estuary in relation to the Tamar Estuary; and (c), the Lynher Estuary showing distances from Notter Bridge and station positions.

Figure 2. Time series of depth-averaged data close to HW between August 2002 and August 2003 for stations at the Lynher mouth (filled squares) and in the tidal river (open circles): (a), water temperature; (b), salinity; (c), SPM concentration; (d), chlorophyll-a.

Figure 3. Contour plots of survey data close to HW along the Lynher for a large spring tide on 10 September, 2002: (a), temperature; (b), salinity; and (c), SPM concentration.

Figure 4. Lynher depth-averaged SPM concentrations (filled squares) and depth-averaged salinity (open circles) close to HW plotted along the Lynher for surveys between August 2002 and July 2003, (a)-(1).

Figure 5. Lynher surface chlorophyll- $a$ concentrations (filled squares) and surface salinity (open circles) close to HW plotted along the Lynher for surveys between September 2002 and July 2003, (a)-(1). 